\title{
Culture, Openness, and FinanCe
}

\author{
by
}

René M. Stulz and Rohan Williamson*

December 2001

* Respectively, Reese Chair in Banking and Monetary Economics, Fisher College of Business, The Ohio State University, and NBER, and Assistant Professor, Georgetown University. We are grateful for useful conversations with Ed Glaeser, Lee Pinkowitz, Raghu Rajan, Patricia Reagan, Andrei Shleifer, and Luigi Zingales, for comments from Asli Arikan, Andrew Karolyi, Bernadette Minton, Ralph Walkling, Karen Wruck, from participants at seminars at Georgetown University and the Ohio State University, and from participants at the Georgia Tech Conference on International Finance. 


\begin{abstract}
This paper uses religion and language as proxies for culture and investigates how these proxies are related to investor rights. We find that a country's principal religion helps predict the cross-sectional variation in creditor rights better than a country's openness to international trade, its language, its income per capita, or the origin of its legal system. Catholic countries protect the rights of creditors less than other countries and have less private long-term debt. A country's openness to international trade mitigates the influence of religion on creditor rights. Our culture proxies are also important predictors of how countries enforce rights, but they have little correlation with shareholder rights.
\end{abstract}


"Max Weber was right. If we learn anything from the history of economic development, it is that culture makes almost all of the difference."

Landes (2000)

\section{Introduction.}

There is substantial evidence that financial development benefits economic growth. ${ }^{1}$ Across countries, there are significant differences in the importance of capital markets, in firms' ability to access external finance, and in the ownership of publicly traded firms. As La Porta, Lopez-de-Silanes, Shleifer, and Vishny (2000) show, a common element explaining these differences is the extent to which investors are protected from expropriation by managers, controlling shareholders, and governments. Policymakers, economists, and journalists have argued that the appropriate model for the protection of the rights of investors is the so-called Anglo-Saxon model. Nevertheless, countries that protect their investors as the U.S. and the U.K. do are in the minority. This is so despite the fact that, as the competition for capital becomes more global, countries with poor protection of investor rights apparently lose out to countries with better protection of investor rights. Why is it then that the degree of investor protection differs across countries?

This paper explores whether differences in culture, defined as a system of beliefs that shape the actions of individuals within a society, can help explain differences in investor protection. The view that culture is an important determinant of economic institutions has a long tradition, dating back at least to the work of Weber (1930). This tradition provides powerful arguments for why some cultures are more supportive of financial markets than others. In his influential work, Weber (1930) argued that cultural changes, namely the Calvinist reformation, played a critical role in the development of capitalism and its

\footnotetext{
${ }^{1}$ See Levine (1997) for a review of the literature.
} 
institutions. Many others have emphasized the importance of Western individualism as an explanation for the growth of markets in the West (see, for instance, Lal (1999) and the references therein). In a seminal paper on the role of culture as a determinant of institutions, Greif (1994) compares Maghribi traders of the eleventh century and Genoese traders of the twelfth century and concludes that "Differences in the societal organization of the two trading societies can be consistently accounted for as reflecting diverse cultural beliefs." (p. 914). He states that his "findings suggest the theoretical and historical importance of culture in determining societal organizations, in leading to path dependence of institutional frameworks, and in forestalling successful intersociety adoption of institutions." (p. 914).

Religions are a key component of systems of beliefs. Historically, religions have had a lot to say about the rights of creditors and less about the rights of shareholders. As Tawney (1954) shows, the prohibition of usury was a fundamental tenet of the medieval church. Usury meant receiving interest on loans and led to excommunication. The Council of Lyons (1274) even prescribed excommunication for anybody who would let a house to a usurer. The medieval church was intent on restricting economic transactions to those where one of the parties would not be taking advantage of the other because of greater bargaining strength. The Calvinist reformation viewed the payment of interest as a normal part of commerce, thereby making it possible for modern debt markets to develop. In the aftermath of the Calvinist reformation, creditor rights differed sharply across Protestant and Catholic countries. This raises the question of whether these differing attitudes toward creditor rights have persisted sufficiently to help understand the variation in creditor rights across countries in the late $20^{\text {th }}$ century. Though the declaration of Pope Pius XII in 1950 that bankers "earn their livelihood honestly"2 suggests that it may not have, the fact that Catholic leaders argue that the distinguishing feature of Catholic social thought from the Protestant Anglo-Saxon culture is that it does not "regard private property and its economic benefits as absolute goods. They are subject to the good

2 See Noonan (1957), p. 377. 
of society." ${ }^{3}$ is consistent with the argument that religions differ in their assessment of investor rights and that empirical evidence can help understand whether these differences matter for investor rights.

Cultures change and adapt in response to economic changes, but they generally do so slowly. If predominant values in some countries are less supportive of market interactions than in other countries, one would expect investor rights to be less well protected in these countries for a number of reasons. First, the case to strengthen these rights is less compelling to their citizens and politicians. Second, these countries might have institutions fostered by their culture that make financial markets less valuable. For instance, extended families limit the use of markets for individuals since many transactions take place within the extended family that otherwise would require the use of markets. Third, these countries might have different economic fundamentals that make market interactions less valuable. For instance, Glaeser and Scheinkman (1998) provide a model where usury laws serve as a primitive means of social insurance. In their model, economic conditions can make such laws useful. At the same time, however, the existence of such a form of social insurance makes financial innovations less profitable and hence slows down financial development. With this view, if culture explains differences in investor protection, it is because it proxies for more fundamental differences in economic conditions or endowments across countries.

We examine whether simple proxies for culture are helpful in understanding how investor rights differ across countries. Religion is widely used as a proxy for culture. For instance, La Porta, Lopez-deSilanes, Shleifer, and Vishny (1999) use religion as a proxy for culture in their study of government quality. Besides religion, it can be argued that beliefs are more easily communicated among countries that share the same language and therefore are more likely to be common among such countries. This would suggest that Anglo-saxon type investor protection would be more likely to be observed in English-speaking countries. We therefore use language as our second proxy for culture. It is hard to argue that these proxies depend on the degree of financial development, so that we do not have to worry about reverse-causation arguments.

3 “America’s Hispanic Future,” by Msgr. Lorenzo Albacete, The New York Times, A27. 
We choose few and extremely simple proxies of culture for two reasons. First, our study uses 49 countries. Since there are few countries, there is a substantial risk of overfitting. Some combination of a suitable number of cultural variables could end up explaining the diversity in shareholder and creditor rights spuriously. Overfitting is not a problem with our choice of proxies and there is much precedent for using them in social sciences. Second, providing a complete explanation of how cultural variables help understand the diversity in investor rights is beyond the scope of this paper. Rather, we want to investigate whether cultural variables have to be taken seriously in explaining that diversity. Strikingly, after controlling for income per capita, language and/or religion are almost always significant in regressions attempting to predict the degree of investor protection.

La Porta, Lopez-de-Silanes, Shleifer, and Vishny (1998) show that the legal origin of a country's laws explains the degree of investor protection in that country. Common law countries protect investors better than civil law countries. There is some debate as to why it is so. One reason could be that the state has a smaller role in common law countries than in civil law countries. ${ }^{4}$ Another reason could be that common law leaves more room for judges to adapt to changes in the economy and to invoke fairness arguments. In a civil law country, the judge interprets the law like a theologian interprets the bible. He has no flexibility in how he can render his decisions. In contrast, common law judges have much more flexibility since they can refer to precedents and can create precedents of their own. Viewed this way, it would seem that the advantage of common law countries is that the enforcement of laws can adapt to changes in the economy. Because civil law countries limit the power of judges, only those attempts to take advantage of investors that are codified can be reversed and punished. This means that managers or controlling shareholders who are intent in taking advantage of investors can use the legal code as a roadmap for permissible expropriation in

${ }^{4}$ See La Porta, Lopez-de-Silanes, Shleifer, and Vishny (1999). Glaeser and Shleifer (2000) provide a model where common law emerges as an efficient solution to the problem of designing a legal system when "the law and order environment is benign to begin with" while civil law emerges as the efficient solution in countries with weak law and order to begin with. 
a civil law country. In contrast, in a common law country, a judge could invoke fairness arguments to force restitution to expropriated investors even though the acts expropriating investors are not specifically prohibited by law.

After showing that language and religion are helpful in understanding differences in investor protection across countries, we examine whether culture proxies are successful because they happen to be correlated with legal origins. It turns out that this is only partly the case. When we consider shareholder rights, culture proxies seem to matter mostly but not exclusively because they are correlated with legal origins. For instance, shareholder rights are better protected in Protestant countries with common law legal origins than in such countries with civil law origins. Our work therefore strengthens the existing evidence on the importance of legal origins insofar as shareholder rights are concerned. However, culture proxies seem to be more important than legal origins for creditor rights. Creditor rights are strongest in countries where the main religion is Protestant regardless of legal origin. Within civil law countries, the protection of creditor rights is weaker in Catholic countries. There is no difference in creditor protection between common law Protestant countries and civil law Protestant countries, but there is a strong difference among civil law countries between Catholic countries and Protestant countries. Finally, when we consider the enforcement of rights, there is clear evidence that religion, language, and legal origins all play a role. Protestant countries have better enforcement of rights than Catholic countries, but for some variables this difference disappears once we also allow for language to play a role.

Several authors have emphasized the importance of politics in understanding why shareholder and creditor rights differ across countries. Roe (2000) argues that the existence of strong redistributive or socialistic movements is more important than legal origins in explaining why financial markets play a weaker role in some countries than in others. However, Beck, Demirgüç-Kunt, and Levine (2001) conduct a horse race between legal origins and political determinants of financial development and conclude that legal origins are more important than political determinants. Rajan and Zingales (2000) point out that countries where 
financial markets were highly developed at the turn of the $20^{\text {th }}$ century became hostile to financial markets during that century. They reason that changes in economic conditions can make it particularly valuable for established firms to oppose new entrants. In such situations, established interests find it optimal to oppose financial markets since they permit new entrants to obtain funding. Legal origins or cultural variables cannot explain why such changes take place. However, both types of variables can explain why investor protection might evolve differently across countries in response to changes in economic conditions. If greater investor protection becomes more valuable because of changes in economic conditions, common law countries or countries with a culture that is more favorable to market interactions could improve investor protection faster and more effectively than other countries.

Rajan and Zingales (2000) argue that trade openness is a proxy for the extent to which it is advantageous for established interests to restrict entry to markets, so that one would expect investor rights to be more protected in countries that are more open to international trade. At the same time, however, one would expect countries that benefit more from international trade to have better investor protection. Trade has to be financed. Trade financing does not take the form of equity stakes, but rather of credits. Consequently, one would expect openness to be more closely tied to creditor rights than to shareholder rights. We find that, as countries become more open, the relation between religion and creditor rights becomes less important.

Finally, we address the question of whether culture and legal origins affect different aspects of financial development. The answer is yes. Stock market development depends on a country's legal origin. In contrast, debt markets and banking development depend on culture. In particular, we document that debt issuances relative to GNP are smaller in Catholic countries than in Protestant countries.

The paper proceeds as follows. In section 2, we motivate our proxies for culture and show the data we use for our study. In section 3, we investigate the relation between rights variables and culture proxies. In section 4, we attempt to ascertain whether the success of the culture proxies is simply due to their 
correlation with legal origin variables. In section 5, we investigate whether investor rights are stronger in countries that are more open to international trade and whether the significance of our cultural variables is due to possible correlation of these variables with openness to international trade. Section 6 shows a direct relation between financial development measures and our culture variables and extends the analysis allowing for differences in the type of civil law a country has. Section 7 concludes.

\section{Section 2. Culture proxies: Motivation and data.}

The data on legal families, shareholder rights, creditor rights, and the rule of law is taken from La Porta, Lopez-de-Silanes, Shleifer, and Vishny (LLSV, 1998). The sample includes 49 countries from Asia, Europe, North America, South America, Africa, and Australia. It does not include countries that recently were socialist countries. To be included in the sample, the countries had to have at least five non-financial publicly traded firms with no government ownership as of 1993. The number of countries specifies the number of observations for the dependent variable in our regressions.

As explained by LLSV and in further detail by Beck, Demirgüç-Kunt, Levine (2001), the Scandinavian, German, and French civil law traditions differ. However, there is debate about what these distinctions really mean. In particular, recent work by Nenova (2000) creates the puzzle that the benefits from control are lower in countries with a Scandinavian civil law tradition than in common law countries. Coffee (2001) makes the point that the Scandinavian civil law tradition is sufficiently like other civil law traditions that the lower benefits from control in Scandinavian countries cannot be explained by differences in legal regimes. Instead, Coffee (2001) argues that “social norms in Scandinavia may discourage predatory behavior by those in control of the firm." Differentiating civil law traditions finely may simply amount to having a dummy variable for Scandinavian countries that picks up the effect of these norms. The norms that Coffee (2001) focuses on reflect the influence of culture rather than law. All Scandinavian countries are Protestant countries. Though we can compare civil law Protestant countries to civil law Catholic countries, sample sizes 
are too small to compare Protestant countries with Scandinavian civil law to other civil law countries. We therefore shy away from differentiating the civil law traditions finely and contrast civil law countries to common law countries as is common in regression analyses (see, for instance, LLSV). Assuredly, one could make a different choice. We therefore show in Section 6 that the key result of this paper, namely that law matters more than culture for shareholder rights but less than culture for creditor rights is not affected by this choice.

Our aim is to test whether simple culture proxies can help explain the diversity in the protection of investor rights consistently across countries. ${ }^{5}$ We therefore restrict our choice to just language and religion as proxies for culture. We use the 2000 CIA World Factbook to obtain each country's primary religion and primary language. These proxies have a long tradition that motivates their use. We define the primary religion (language) as the religion (language) that is practiced by the largest fraction of the population of a country. The Anglican religion is included in the Protestant religion. For most countries, more than half the country practices the primary religion. In Canada, Germany, and Holland, the fraction of the population practicing the Catholic religion is close to the fraction practicing the Protestant religion. In Korea, the fraction of the population that is Protestant is only slightly larger than the fraction of the population that is Buddhist. ${ }^{6}$ Our results do not seem sensitive to the classification of the religious affiliation of these countries. Our approach differs from La Porta, Lopez-de-Silanes, Shleifer, and Vishny (1999) and Beck, DemirgüçKunt, Levine (2001), who use the fraction of a country that practices a given religion in the multiple regressions in their study of the determinants of the quality of governments. We proceed the way we do because we believe that, if religion matters, the religion that is practiced by the largest fraction of a country

${ }^{5}$ There is a literature that combines multiple indicators to measure culture (see Hofstede (1980)). We concluded that using language and religion would lead to clearer results than modeling culture along dimensions such as uncertainty avoidance and tolerance of power distance.

${ }^{6}$ The 2000 CIA Factbook states that $49 \%$ of the population is Christian and $47 \%$ is Buddhist. The 1997 CIA Factbook used Protestant instead of Christian, so that we use Protestant also. 
should have a unique influence on that country, so that we would not expect the impact of religion to increase linearly with the fraction of the population of a country that practices a religion.

Hallpike (1986) emphasizes the existence of core principles of societies that are extremely persistent and include a world-view. He states that "The evidence that societies have core principles is very substantial. Cross-culturally, we constantly find that groups of societies with common origins (as shown particularly in membership of the same language family) share many basic features of organization and world-view that cannot be explained on adaptive or functional grounds." (p. 293). When considering the role of financial markets across countries, it is typical to talk about an Anglo-Saxon model. This model is one with diffuse ownership where stock markets play a crucial role in the allocation of capital. We therefore ask whether countries where English is the primary language are countries where shareholder and creditor rights are different from other countries. Table 1 provides a list of countries and shows which countries use English as their primary language. We see there that English is the primary language for ten countries. The Spanish language is the only other language that is shared by a significant number of countries since eight countries have Spanish as their primary language.

Since Weber's work, religion has been viewed as a key determinant in the growth of capitalism. Lal (1999) argues that "...cosmological beliefs - an essential element of "culture" - have been crucial in the rise of the West and the subsequent evolution of its political economy." (p. 174). There is, however, some controversy as to whether capitalism and its institutions were fostered by the Protestant reformation as suggested by Weber or emerged earlier. Lal (1999) argues that individualism "is the unique cosmological belief of the West." (p. 174) in contrast to the communalism prevalent in the rest of the world. We therefore consider whether investor rights differ in countries where the primary religion is Christian as well as whether rights differ between Protestant and Catholic countries. Table 1 shows that the Christian religion is the primary religion in 32 out of 49 countries. Of these 32 countries, 12 countries have Protestantism as their primary religion. Seven countries have the Muslim religion as their primary religion and in five countries, 
Buddhism is the primary religion. No other religion is the primary religion in more than two countries in our sample.

\section{Section 3. Culture proxies and investor rights.}

Table 2 shows how investor rights differ according to whether a country's primary language is English or not, whether the country's primary religion is Christian or not, and finally, when the primary religion is Christian, whether it is Protestant or Catholic. In the first three parts of this section, we discuss how shareholder rights, creditor rights, and the enforcement of investor rights differ according to these religion and language proxies. In the fourth part of this section, we present multiple regressions that allow us to control for income per capita and increase the number of language and religion proxies we use.

\section{Section 3.1. Shareholder rights.}

Panel A of Table 2 considers shareholder rights. The first right is whether a country mandates one share one vote. Departures from one share one vote enable shareholders who control less than a majority of cash flow rights to make decisions for the firm. Strikingly, no English-speaking country mandates one share one vote. Religion does not affect whether one share one vote prevails. The next six measures are denoted by LLSV as anti-director rights. They combine these six measures into an anti-director rights index. Each variable for anti-director rights is a dummy variable that takes value one if a right is mandated in a country and zero otherwise. The value of the index is obtained by adding the dummy variables for the six rights. The index provides a summary of how rights differ across countries with different cultures. Anti-director rights are stronger in English-speaking countries. The differences in the index are not significant between Christian and non-Christian countries or between Protestant and Catholic countries.

Looking at the various anti-director rights, English-speaking and Protestant countries make it easier for shareholders to vote. No English-speaking country blocks shares before the shareholder meeting, so that 
shareholders in these countries do not have to deposit their shares with the company to be able to vote. A majority of the English-speaking countries allow voting by mail. Cumulative voting or proportional representation make it easier for minority shareholders to be represented on the board. Catholic countries are significantly more likely to have cumulative voting or proportional representation, but the other cultural distinctions we make do not matter. All English-speaking countries have some mechanism for shareholders to pursue redress against decisions of the company that they believe to be harmful. Less than half of the nonEnglish speaking countries have such a mechanism. Religion seems irrelevant for the existence of such a mechanism. Preemptive rights enable shareholders to have first right to buy new shares issued by the company. Such a mechanism protects minority shareholders from having controlling shareholders sell shares cheaply to some subsets of investors. Preemptive rights are more likely in non-English speaking countries. Three-quarters of the Catholic countries have such rights, in contrast to less than half the Protestant countries. Finally, the last variable in the index takes value one if less than $10 \%$ of the shareholder votes are required to call a shareholder assembly. Non-English speaking countries and Catholic countries have lower requirements to call a shareholder assembly.

The last right considered by LLSV is whether there is a mandatory dividend law or rule. The mandatory dividend variable takes value zero if a country has no minimum dividend and is equal to the decimal minimum dividend otherwise. No English-speaking country has such a minimum-dividend rule and no Protestant country has such a rule. Catholic countries are much more likely to have such a rule than Protestant countries.

In summary, English-speaking countries and Protestant countries make it easier for shareholders to vote and sue, but harder to make their vote count when they vote.

\section{Section 3.2. Creditor Rights.}

Panel B of Table 2 shows how creditor rights vary across countries that differ in religion or language. 
Panel B of Table 2 is sharply different from Panel A of the same Table. Looking across the various creditor rights variables, language is largely unimportant while religion is crucially important. The first right is whether the reorganization procedure imposes an automatic stay on secured assets. In the presence of such a stay, secured creditors cannot get possession of the collateral in a reorganization. The dummy variable takes value one if there is no automatic stay. The results for that dummy variable turn out to be similar to the results for most of the creditor rights: language does not matter, but since Catholic countries protect the rights of creditors poorly, non-Christian countries are better for creditor rights than Christian countries. The next variable takes value one if secured creditors are paid first. This dummy variable does not differ significantly across culture proxies, but the sign of the differences is the same as with the first dummy variable considered. The third variable takes value one if there are restrictions to going into reorganization. Again, language does not matter, but non-Catholic countries are more likely to impose restrictions. An important issue in a reorganization is whether management stays in control. The dummy variable takes value one if management does not stay in control during the reorganization process. It is highly unusual for management to stay in control in non-Christian countries, but management almost always stays in control in Catholic countries. The final variable is a dummy variable that takes value one if there is a minimum amount of share capital required for a firm not to be dissolved. No English speaking country has such a rule. The existence of such a rule does not seem to be related to a country's primary religion.

LLSV combine the first four creditor rights into an index by assigning a value of one for any of the rights a country has. The creditor rights index shows that creditor rights are higher in non-Christian countries than in Christian countries and higher in Protestant countries than in Catholic countries. Of all the groups of countries we consider, the Catholic group has the lowest index, 1.32.

\section{Section 3.3. Enforcement of rights and accounting standards.}

So far, we have examined how shareholder rights and creditor rights are correlated with our culture 
proxies. The rights we considered were rights specified in laws or statutes. The enforcement of these rights differs across countries. We therefore now consider variables that measure the extent of enforcement of these variables. The value of each index increases with enforcement. Panel $\mathrm{C}$ of Table 2 provides the results for sample splits based on culture proxies for various enforcement variables and for accounting standards.

Before looking at the results for the individual variables, we can summarize the results of that Panel as follows. First, language is irrelevant except for accounting standards. Second, religion matters a great deal. Christian countries typically have better enforcement. The strongest result is, however, that for every variable, enforcement is significantly stronger for Protestant than for Catholic countries. The first variable is a measure of the efficiency of the judicial system produced by a country risk rating agency. LLSV use the average from 1980 to 1984 . This variable is the same whether countries have English as their primary language or not and whether countries are Christian or not. However, its score is significantly higher for Protestant countries than for Catholic countries. The next four variables are significantly higher for Christian countries than for non-Christian countries and significantly higher for Protestant countries than for nonProtestant countries. These variables are all indexes produced by the country rating agency International Country Risk (ICR). The first variable measures the rule of law. The second variable estimates the extent of corruption in government. The third variable assesses the risk of expropriation. The fourth variable is an index capturing the risk of expropriation by the government. All ICR indices used by LLSV are averages from 1982 through 1995 and are scaled so that their values go from one through ten, with one representing the worst possible enforcement and ten the highest. The final variable in the table is an index of accounting standards produced by the Center for International Financial Analysis and Research. With this index, English speaking countries have better accounting standards than other countries and Protestant countries have higher standards than Catholic countries. 


\section{Section 3.4. Multiple regression analysis.}

The comparisons in Table 2 do not take into account the state of development of countries. Further, it is only possible to make comparisons between two groups at a time. We estimate multiple regressions that include GNP per capita as an explanatory variable. We would expect that investor rights are better protected in richer countries. We therefore want to make sure that our culture proxies do not proxy for GNP per capita. At the same time, however, such an approach may lead us to understate the impact of culture. La Porta, Lopez-de-Silanes, Shleifer, and Vishny (1999) find that Catholic countries have lower quality government, but their results are not significant when they control for GNP per capita. Their interpretation is that " the adverse effect of the religious affiliation on the quality of the government is in part captured by per capita income." With this view, GNP per capita is affected by culture, which makes it harder to estimate precisely the relation between investor protection and culture. With the multiple regression, we can also use additional culture proxies. We use dummy variables PROTESTANT, CATHOLIC, BUDDHIST, MUSLIM, ENGLISH, and SPANISH. These variables take value one if a country's primary religion or language is the one of the name of the dummy variable and zero otherwise. Table 3 presents some of the regressions. We only present regressions for the anti-director rights index, the creditor rights index, and the enforcement and accounting indices. We estimated regressions for the individual shareholder and creditor rights, but including these regressions in our discussion would not affect our conclusions.

The regressions for the anti-director rights index as the dependent variable are reproduced in Panel A of Table 3. The first regression uses the dummies PROTESTANT and CATHOLIC in addition to a constant and the log of GNP per capita. There is no significant difference between the coefficients of the religion dummies. The second regression adds the dummies BUDDHIST and MUSLIM. None of the coefficients on the religion proxies are significant or significantly different from each other. The difference between the PROTESTANT and CATHOLIC dummies has a p-value of 0.13, though. The third regression

uses the dummies ENGLISH and SPANISH. Countries whose primary language is ENGLISH have a 
significantly higher anti-director rights index than countries whose primary language is SPANISH or than other countries. In these regressions, GNP per capita is not significant. The results therefore confirm our conclusions in Section 3.1. and taking into account additional culture proxies has no impact on our conclusions.

Panel B of Table 3 shows regression estimates using creditor rights index as the dependent variable. It is immediately clear from the first regression that whether a country's primary religion is Catholic instead of Protestant matters a great deal. The coefficient on the CATHOLIC is negative and has a t-statistic of -4.17. The regression has an adjusted $\mathrm{R}^{2}$ of $40 \%$. The second regression shows that CATHOLIC remains significant when we add BUDDHIST and MUSLIM to the regression. These additional dummies are not significant. All religion dummies are significantly different from the Catholic dummy. The result for MUSLIM seems surprising since the Qur'an prohibits the charging of interest and some fundamentalist countries still have this prohibition. It may be that this result can be explained by the absence of the fundamentalist countries in our sample. However, as Kuran (2001) points out, "In the early Islamic centuries the Middle East featured money changers, moneylenders, and pawnbrokers, along with "merchant bankers" who, in the course of their commercial activities, accepted deposits, provided credit, intermediated the payment of debts through the delegation of credit (hawala), and issued bills of exchange that could be cashed in distant lands (suftaja)." (p. 16.) In other words, Muslim countries were not antagonistic to banking activities that require protection of creditor rights, but only to the charging of interest. The last regression of the panel shows that countries with Spanish as the primary language have lower creditor rights than other countries, but countries with English as the primary language do not have creditor rights that differ significantly from countries other than those with Spanish as the primary language. Per capita income is insignificant for the first two regressions, but not for the last one. This provides support for the argument in La Porta, Lopez-de-Silanes, Shleifer, and Vishny (1999) that GNP captures part of the effect of religion.

Panel C of Table 3 shows regression estimates for the enforcement of rights. Looking first at judicial 
efficiency, there is a significant difference between the coefficients on CATHOLIC and PROTESTANT in the first regression. In the next regression, the coefficient on CATHOLIC is significantly negative and significantly different from the coefficient on PROTESTANT. The other coefficients on the dummy variables are not significant and do not differ significantly from each other. Finally, when we turn to the language regression, we find that judicial efficiency is higher in countries where English is the primary language. None of the religion dummies are correlated with the rule of law index, but the rule of law index is significantly higher for English-speaking countries than for Spanish-speaking countries. The Protestant countries have a significantly higher corruption index than all other countries (remember that a higher corruption index means less corruption). When we add dummy variables for Buddhist and Muslim countries, Protestant countries remain different and have a higher corruption index than Catholic, Buddhist, or Muslim countries. There is an extremely sharp difference in the corruption index between countries whose primary language is Spanish and those whose primary language is English. SPANISH is significantly negative and ENGLISH is significantly positive. Turning to expropriation risk, once more the only religion difference that matters is the one between Protestant and Catholic countries. Spanish-speaking countries have a significant negative coefficient. The results are similar for repudiation risk, except that both Protestant and Buddhist countries have a higher index than Catholic countries. Finally, the accounting index is significantly lower in Catholic countries. The difference in the index between Catholic and Protestant countries is significant. Perhaps not surprisingly at this point, English-speaking countries have a significant positive coefficient and Spanishspeaking countries have a significant negative coefficient.

\section{Section 4. Is it culture or legal origins?}

LLSV show that differences in investor protection are highly correlated with differences in legal origin. Common law countries have better investor protection than civil law countries. Culture could matter simply because it is correlated with legal origin. The dataset gives us some ability to distinguish between a 
legal origin explanation and a cultural explanation for differences in investor protection across countries. However, no civil law country has English as its primary language, all countries with Spanish as their primary language are Catholic, and no common law country has Spanish as its primary language. First, we can distinguish between English-speaking common law countries and other common law countries. Second, there are 12 Protestant countries. Of these countries, six are common law countries and six are civil law countries. We can therefore investigate whether legal origins matter for Protestant countries. Only one Catholic country has common law, so that we cannot distinguish meaningfully between catholic common law and civil law countries.

We have seen that for creditor rights and for legal enforcement, there are strong differences between Catholic and Protestant countries. If these differences can be explained by differences in legal origins, we would expect significant differences among Protestant countries depending on their legal origins and no significant differences between Protestant and Catholic civil law countries. To investigate these differences, we use regressions where we interact culture proxies and legal origins. If legal origins do not matter, the impact of culture has to be the same regardless of legal origins.

To limit the number of regressions we show, we reproduce in Table 4 only regressions for the shareholder rights index and for the creditor rights index. The first regression shows that for shareholder rights, religion does not seem to matter after taking into account legal origin. Common law Protestant countries have significantly better shareholder rights than civil law Protestant countries. In contrast, civil law Protestant countries have insignificantly different shareholder rights from civil law Catholic countries. Consequently, differences in shareholder rights cannot be explained by differences in religion but can be explained by differences in legal origins. The second regression compares whether there is a difference between English-speaking common law countries and other common law countries as well as between Spanish-speaking civil law countries and other civil law countries. Controlling for legal origins, none of the language differences are associated with significant differences in shareholder rights. 
The second set of regressions in Table 4 investigates the relation between creditor rights, culture proxies, and legal origins. The results are sharply different from those for shareholder rights. First, there is no difference between common law Protestant countries and civil law Protestant countries. Second, there is a significant difference between civil law Protestant countries and civil law Catholic countries. The second regression shows that English-speaking common law countries have lower creditor protection than nonEnglish speaking common law countries. In fact, there is no difference between English-speaking common law countries and civil law countries that do not speak Spanish.

Our evidence shows that legal origins are not as important for creditor rights as the branch of Christianity a Christian country belongs to. It is interesting to note that civil codes seem to support our conclusion. If legal origin were the main determinant of the attitude of a country towards creditors, one would expect different civil codes to treat creditors similarly. However, this is not the case. Article 1162 of the French Code states that "In cases of doubt, one should construe the contract against the creditor and in favor of the debtor.", while the German civil code "places greater emphasis on the explicit "expression" of the contract, which implies great emphasis on the rights of creditors relative to debtors." 7

We now turn to the enforcement variables There is never a significant difference between common law Protestant countries and civil law Protestant countries. Except for the judicial efficiency and rule of law indices, we cannot reject the hypothesis that enforcement is worse in civil law Catholic countries than in civil law Protestant countries. The bottom line from these regressions is that when it comes to enforcement, we find that culture matters but cannot establish that legal origins matter.

Given the data limitations, it is perhaps more surprising that we can find that something matters than that we cannot when we try to distinguish between the effect of legal origins and the effect of our culture proxies. In the regressions of Table 4, we have five different independent variables to estimate jointly the Code.

${ }^{7}$ Beck, Demirgüç-Kunt, Levine (2001), p. 19. They also cite the article from the French Civil 
religion and law origin effects. Because we are splitting a sample of 49 countries into five different groups and because there is only one common law Catholic country, it makes sense to use a more conservative test to see whether there is a role for religion when one takes into account legal origins. We estimate regressions of the rights variables on a constant, a dummy that takes value one for civil law countries, CIVOR, and the logarithm of GNP per capita. We then add to these regressions PROTESTANT and CATHOLIC. If religion proxies for legal origins, the religion dummy variables should not be significant in these regressions. We do not report these regressions in a table. One would expect the religion proxies not to be significant for shareholder rights and they are not. The results for creditor rights are dramatic. In the regression with CIVOR and the $\log$ of GNP per capita, CIVOR has a coefficient of -1.18 with a t-statistic of -2.83 . The regression has an adjusted R-square of $24 \%$. When we add the religion dummy variables, the adjusted R-square increases to $42 \%$. CATHOLIC has a coefficient of -1.57 with a t-statistic of -3.63 . The coefficient on the civil law dummy variable is -0.54 with a t-statistic of -1.59 , so that it is not significant at the $10 \%$ level. CIVOR is significant in the presence of the religion variables for judicial efficiency, corruption, and the accounting index. For the other enforcement indices, CIVOR is significant in the absence of the religion variables for all indices except the rule of law index. When the regression includes the religion proxies, CIVOR stops being significant for the repudiation risk index and the expropriation risk index. The difference between PROTESTANT and CATHOLIC is significant for these indices. For the corruption and accounting indices, CIVOR is significant but so is the difference between PROTESTANT and CATHOLIC. Finally, for judicial efficiency, CIVOR is significant, but the significance of the difference between PROTESTANT and CATHOLIC disappears when CIVOR is added to the regression. In summary, in most of the regressions, the difference between PROTESTANT and CATHOLIC is significant when we add a dummy variable for civil law. 


\section{Section 5. Politics, openness, and finance.}

Financial development did not evolve linearly through time. As Rajan and Zingales (2000) show, financial development was high before World War I. They also report that some civil law countries had a very high level of financial development. However, the period preceding World War I represents a high point of financial development that would not be matched again, at least for some indicators of financial development, until after 1980 for many countries. Both the legal origin variables of LLSV and the culture proxies we use in this paper remained largely unchanged during the $20^{\text {th }}$ century for our sample countries. These variables cannot therefore explain why financial development fell and then increased again during that century. Rajan and Zingales (2000) argue that financial development is critically related to a country's openness to trade and capital flows. They show that, both before World War I and in the late $20^{\text {th }}$ century, countries that are more open have greater financial development. A possible explanation for this finding is that openness serves as a proxy for the benefits from letting markets work unimpeded. As political forces that oppose markets get the upper hand, perhaps because the median voter finds the lack of security resulting from the working of markets to be too costly, countries close their frontiers so that economic transactions can be controlled more closely by the government.

As we pointed out in the introduction, international trade has to be financed. There can therefore be a mechanical relation between openness as measured by international trade and investor rights, especially creditor rights. The international trade literature has measures of natural openness. These measures estimate what the openness of a country would be given some characteristics of that country. Such measures are helpful here because they eliminate the possibility of a mechanical relation between our measure of openness and investor protection. These measures can be used to proxy for the incentives a country has to protect investor rights to benefit from trade. We need a measure of openness that depends on exogenous variables. Frankel and Romer (1999) compute a measure of natural openness that satisfies our requirement. That measure is based only on geographic characteristics and uses a gravity model that presumes that countries 
closer to each other trade more with each other. ${ }^{8}$

Since openness can lead countries to value investor rights more or can be correlated with better investor rights as countries become more market oriented, we would like to know whether openness matters for investor rights and whether the success of our religion and language dummy variables is due to their possible correlation with openness. To examine these issues, we regress investor rights measures on our culture proxies, natural openness, the log of GNP per capita, and CIVOR. We report the results in Table 5.

The results for the shareholder rights index regressions are striking. The coefficient on openness is negative and significant. ${ }^{9}$ Countries that are more open have lower shareholder protection. This negative coefficient is largely due to an extremely strong negative relation between openness and the dummy variable for cumulative or proportional voting. In the regressions, the dummy variable for civil law, CIVOR, is extremely significant and negative. None of the culture variables matter for the shareholder rights regressions, which does not change our earlier conclusions.

When we turn to creditor rights, openness has a significant positive effect on creditor rights. Adding actual openness does not affect the adjusted R-square, but adding natural openness increases it by $8 \%$. CIVOR is insignificant. As before, CATHOLIC has a negative significant impact on the creditor rights index. CATHOLIC does not proxy for openness in our regressions - it remains significant regardless of whether we control for legal origins or openness.

As discussed earlier, one would expect there to be larger incentives for a country to respect creditor rights when international trade is more important for that country. We examine whether the importance of

${ }^{8} \mathrm{We}$ also used actual openness measured by the average ratio of international trade over GDP as well as alternate measures of natural openness provided by Frankel and Romer (1999) and Wei (2000). Finally, we used Wei's measure of residual openness, which is the difference between his measure of natural openness and actual openness. Wei's measure of natural openness has language as one of its determinants, so that it includes one of our culture proxies. We discuss, when appropriate, how the results differ with these measures.

9 Actual openness explains less than natural openness - adding actual openness to the regression increases adjusted R-square by about $2 \%$ and adding natural openness by about $10 \%$. 
religion falls as openness increases in the following way. We estimate a regression where we regress the creditor rights index on a constant, the log of GNP per capita, PROTESTANT, CATHOLIC, OPENNESS*PROTESTANT, OPENNESS*CATHOLIC, OPENNESS*NON-CHRISTIAN, where NONCHRISTIAN takes value one for all countries where the principal religion is neither Protestant nor Catholic. The estimates and t-statistics using natural openness are as follows:

$5.63-0.37$ Log GNP per capita -

$(-3.23)(-3.24)$
0.19 PROTESTANT - 1.83 CATHOLIC

$(-0.34)$

$(-3.25)$

+0.04 OPENNESS $*$ PROTESTANT $+\quad 0.05$ OPENNESS*CATHOLIC

+0.03 OPENNESS*NON-CHRISTIAN

$(2.82)$

With this regression, we find a significant negative coefficient on CATHOLIC as expected. The coefficient on OPENNESS*CATHOLIC is significantly positive. Perhaps more importantly, it is also larger than OPENNESS*PROTESTANT. The difference of the two interaction terms has a p-value of 0.01 for natural openness and 0.11 for actual openness. None of the other differences are significant. This evidence suggests that as a country's openness increases, the fact that its principal religion is Catholic matters less for creditor rights.

We now turn to the rights enforcement variables. Openness is significant only for the judicial efficiency and the corruption indices. Judicial efficiency increases with openness. Furthermore, when we control for openness, judicial efficiency is significantly lower in Catholic than in Protestant countries. 
CIVOR is not significant. The corruption index increases with natural openness, which is what one would expect from Wei (2000) who finds such a relation using a different measure of natural openness. In the regression, the coefficient on the civil law dummy variable is significantly negative and the coefficient on PROTESTANT is significantly positive. The coefficient on CATHOLIC is significant, but it is not significantly different from the coefficient on PROTESTANT. Protestant countries have a significantly higher corruption index than Spanish-speaking countries after controlling for legal origins and for natural openness.

\section{Section 6. Financial development and culture.}

We have shown that culture is correlated with the rights that investors have and with how these rights are enforced. The literature shows that investor rights matter for financial development. Our results suggest that our culture proxies should be correlated with financial development. However, because we showed that shareholder rights depended mostly on legal origin rather than culture, we would expect measures of stock market development to be unrelated to our culture proxies. In contrast, we saw that culture is important for creditor rights. Consequently, culture should affect the development of debt markets and banking.

We consider four measures of financial development for which we have data for 36 of our countries or more. We obtain this data from Beck, Demirgüç-Kunt, and Levine (1999) and use averages from 1985 to 1995. These measures are equity issues to GDP, long-term private debt issues to GDP, private credit by deposit money banks and other financial institutions to GDP, and stock market capitalization to GDP. Beck, Levine, and Loayza (2000) show that there is a strong relation between private credit and growth due to the relation between private credit and productivity growth. We estimated regressions of these averages on a constant, logarithm of GNP per capita, natural openness, PROTESTANT, CATHOLIC, ENGLISH, SPANISH, and CIVOR. The only significant variable in explaining equity issues is the dummy variable that takes value one for civil law countries, CIVOR, which affects equity issues negatively. The F-test does not 
allow us to reject the hypothesis that the coefficients are equal to zero. We estimate the same regressions for long-term debt issues. The difference between the coefficients of PROTESTANT and CATHOLIC is significant with a p-value lower than 0.01 . No other variable is significant, but the F-test has a p-value of less than 0.01 . The adjusted R-square of the regression exceeds 45\%. Except for the log of GNP per capita, none of the coefficients in the regression for credit are significant and none of the culture coefficients are significantly different from each other. Finally, for stock market capitalization, CIVOR is significantly negative. The only other variable that is significant in the regressions for stock market capitalization is the logarithm of GNP per capita which is always significantly positive. ${ }^{10}$

The regressions that use openness, legal origin, and the culture variables have two lessons. First, it is clear that religion is important in explaining debt markets, and that legal origins and possibly openness are important in explaining stock market variables. These results reinforce what we learned in the earlier sections: legal origins are important for shareholder rights and culture is important for creditor rights. At the same time, however, the regressions suggest that it is difficult to estimate coefficients precisely because of multicollinearity. An indication that this problem is not trivial is the following. If we regress the financial development variables on the log of GNP per capita, CATHOLIC, and PROTESTANT, we find that for each regression either CATHOLIC or PROTESTANT is significant. Catholic countries have significantly fewer equity issues than other countries, significantly fewer long-term debt issues than Protestant countries, significantly less bank credit than other countries, and significantly lower stock market capitalization. If we use CIVOR instead of the two religion dummy variables, we find that civil law countries have significantly less new equity, significantly lower credit from financial institutions, and significantly lower stock market capitalization.

To understand better which variables are most important in explaining the cross-sectional variation

${ }^{10}$ In general, the results are not sensitive to the choice of a measure of openness, but Wei's residual openness is strongly correlated with stock market capitalization. This result is supportive of the analysis of Rajan and Zingales (2000). 
in financial development, we provide in Table 6 the incremental adjusted R-square for explaining the crosssectional variation in investor rights, enforcement of investor rights, and financial development of adding to a regression with a constant and the log of GNP per capita, a civil law dummy, PROTESTANT and CATHOLIC, ENGLISH, and SPANISH, in and openness.

Ignoring for the moment the last column of Table 6, we see from the other columns that civil law has the highest incremental adjusted R-square for equity variables (anti-director rights, equity issues, stock market capitalization), for judicial efficiency, and for the accounting index. The culture proxies have the highest incremental adjusted R-square for all other dependent variables. Religion matters more for the credit variables (creditor rights, long-term debt issues, private credit) and language matters more for the enforcement variables. The last column of Table 6 uses a finer classification of legal origins. Instead of dividing countries between common law countries and civil law countries, we look at the incremental explanatory power of allowing for a different impact of the three civil law traditions, the French, the German, and the Scandinavian. This finer classification of legal origins does not change our conclusions about the importance of religion for creditor rights, but for the importance of religion relative to legal origins falls for the other variables. To examine this issue further, we also re-estimate the regressions discussed at the end of Section 4 replacing CIVOR with dummy variables for each of the civil law traditions but do not report the estimates. When we do that, CATHOLIC is unaffected in the creditor rights regressions, but perhaps not surprisingly in light of La Porta, Lopez-de-Silanes, Shleifer, and Vishny (1999) and of the fact that all Scandinavian countries are Protestant countries, the coefficients on religion are hard to estimate precisely in the enforcement rights regressions.

The key issue in evaluating these results is whether a case can be made that the differences among civil law traditions are important enough to explain so much of the evidence. As emphasized by Coffee (2001), there is a Scandinavian puzzle. Since the Scandinavian civil law dummy variable is a dummy variable for Scandinavian countries, it could a Scandinavian effect rather than a Scandinavian civil law effect. 


\section{Section 7. Conclusion.}

In this paper, we have shown that investor protection is related to culture. This relation is especially strong for creditor rights. We find that Catholic countries have significantly weaker creditor rights than other countries. This result holds when we control for the origin of the country's legal system as well as for GNP per capita. Openness reduces the influence of religion on creditor rights, so that Catholic countries where international trade is more important have better protection of creditor rights. We therefore find strong support for the view that culture matters, but there is also evidence that the impact of culture is tempered by openness. Though we find evidence that culture and creditor rights are related, we do not find such evidence for a shareholder rights index once we control for the legal origin of a country's legal system. We also showed that culture is related to the enforcement of rights, with Catholic and especially Spanish-speaking Catholic countries having weaker enforcement of rights.

The rights of investors and how these rights are enforced determines much of how corporations are financed and organized, of how financial markets function, and of the assets in which individuals can invest their savings. There is now a large literature showing that financial development leads to economic growth. If investor rights depend mostly on legal origins, countries can do nothing to change their legal origins. If investor rights depend on how individuals view the world, investor rights can improve if individuals can be convinced that these rights lead to faster economic growth and that faster economic growth is worth it. 


\section{References}

Beck, T., A. Demirgüç-Kunt, and R. Levine, 2001, Law, politics, and finance, Unpublished working paper, World Bank, Washington, DC.

Beck, T., R. Levine, and N. Loayza, 2000, Finance and the sources of growth, Journal of Financial Economics 58, 261-300.

Beck, T., A. Demirgüç-Kunt, and R. Levine, 1999, A new database on financial development and structure, working paper, University of Minnesota.

Coffee, J. C., 2001, Do norms matter? A cross-country examination of the private benefits of control, unpublished working paper, Columbia Law School, Columbia, New York, NY.

Frankel, J., and D. Romer, 1999, Trade and growth: An empirical investigation, American Economic Review 89, 379-399.

Glaeser, E. L., and J. Scheinkman, 1998, Neither a borrower nor a lender be: An economic analysis of interest restrictions and usury laws, Journal of Law and Economics, 1-36.

Glaeser, E. L., and A. Shleifer, 2000, Legal origins, working paper, Harvard University.

Greif, A., 1994, Cultural beliefs and the organization of society: A historical and theoretical reflection on collectivist and individualist societies, Journal of Political Economy 102, 912-950.

Hallpike, C. R., 1986, The principles of social evolution, Clarendon Press, Oxford, UK.

Hofstede, G.H., 1980, Culture's consequences: International differences in work-related values, Sage Publications, Beverly Hills.

Kuran, T., 2001, The Islamic commercial crisis: Institutional roots of the delay in the Middle East's economic modernization, USC Center for Law, Economics \& Organization, Research Paper No. C01-12, USC, Los Angeles.

Lal, D.,1999, Unintended consequences: The impact of factor endowments, culture, and politics on long-run economic performance, MIT Press, Cambridge, MA. 
Landes, D., 2000, Culture makes almost all the difference, in Culture Matters, L. E. Harrison and S. P. Huntington, eds., Basic Books, New York, NY.

La Porta, R., Lopez-de-Silanes, F., Shleifer, A., and R. Vishny, 1998, Law and finance, Journal of Political Economy 106, 1113-1155.

La Porta, R., F. Lopez-de-Silanes, F., Shleifer, A., and R. Vishny, 1999, The quality of government, Journal of Law, Economics, and Organization 15, 222-279.

La Porta, R., Lopez-de-Silanes, F., Shleifer, A., and R. Vishny, 2000, Investor protection and corporate governance, Journal of Financial Economics 58, 3-27.

Levine, R., 1997, Financial development and economic growth: view and agenda, Journal of Economic Literature 35, 688-726.

Nenova, T., 2000, The value of corporate votes and control benefits: A cross-country analysis, unpublished working paper, Harvard University, Cambridge, MA.

Noonan, John T., Jr., 1957, The Scholastic analysis of usury, Cambridge University Press, Cambridge.

Rajan, R., and L. Zingales, 2000, The great reversals: The politics of financial development in the $20^{\text {th }}$ century, unpublished working paper, University of Chicago, Chicago, IL.

Roe, M., 2000, Political preconditions to separating ownership from corporate control, Columbia Law School, The Center for Law and Economic Studies, wp 155, New York, NY.

Tawney, R. H., 1954, Religion and the rise of capitalism, Harcourt, Brace \& World, Inc., New York.

Weber, M., 1930, The Protestant ethic and the spirit of capitalism, Harper Collins, New York.

Wei, S.-J., 2000, Natural openness and good government, unpublished working paper no. 7765, NBER, Cambridge, MA 
Table 1. Country characteristics. The table shows the primary language, primary religion, and the origin of the legal system for each country in the sample. The primary religion (language) of a country is the religion practiced (language spoken) by the largest fraction of the population. The data on religion and language is obtained from the 2000 CIA World Factbook. The legal origin variables are obtained from La Porta, Lopez-de-Silanes, Shleifer, and Vishny (1998).

\begin{tabular}{|c|c|c|c|}
\hline Country & Primary Language & Primary Religion & Legal Origin \\
\hline Argentina & Spanish & Catholic & civil/French \\
\hline Australia & English & Protestant & common \\
\hline Austria & German & Catholic & civil/German \\
\hline Belgium & Dutch & Catholic & civil/French \\
\hline Brazil & Portuguese & Catholic & civil/French \\
\hline Canada & English & Catholic & common \\
\hline Chile & Spanish & Catholic & civil/French \\
\hline Colombia & Spanish & Catholic & civil/French \\
\hline Denmark & Danish & Protestant & civil/Scandinavian \\
\hline Ecuador & Spanish & Catholic & civil/French \\
\hline Egypt & Arabic & Muslim & civil/French \\
\hline Finland & Finnish & Protestant & civil/Scandinavian \\
\hline France & French & Catholic & civil/French \\
\hline Germany & German & Protestant & civilGerman \\
\hline Greece & Greek & Greek Orthodox & civil/French \\
\hline Hong Kong & Chinese & Local beliefs & common \\
\hline India & Hindi & Hindu & common \\
\hline Indonesia & Bahasa Indonesia & Muslim & civil/French \\
\hline Ireland & English & Catholic & common \\
\hline Israel & Hebrew & Judaism & common \\
\hline Italy & Italian & Catholic & civil/French \\
\hline Japan & Japanese & Buddhist & civil/German \\
\hline Jordan & Arabic & Muslim & civil/French \\
\hline Kenya & English & Protestant & common \\
\hline Malaysia & Bahasa Melayu & Muslim & common \\
\hline Mexico & Spanish & Catholic & civil/French \\
\hline Netherlands & Dutch & Catholic & civil/French \\
\hline New Zealand & English & Protestant & common \\
\hline Nigeria & English & Muslim & common \\
\hline
\end{tabular}

\section{Table 1, Continued}




\begin{tabular}{llll}
\hline Country & Primary Language & Primary Religion & Legal Origin \\
\hline Norway & Norwegian & Protestant & civil/Scandinavian \\
Pakistan & Punjabi & Muslim & common \\
Peru & Spanish & Catholic & civil/French \\
Philippines & Pilipino & Catholic & civil/French \\
Portugal & Portuguese & Catholic & civil/French \\
Singapore & Chinese & Buddhist & common \\
South Korea & Korean & Protestant & civil/German \\
South Africa & English & Protestant & common \\
Spain & Spanish & Catholic & civil/French \\
Sri Lanka & Sinhali & Buddhist & common \\
Sweden & Swedish & Protestant & civil/Scandinavian \\
Switzerland & German & Catholic & civil/German \\
Taiwan & Chinese & Buddhist & civil/German \\
Thailand & Thai & Buddhist & common \\
Turkey & Turkish & Muslim & civil/French \\
UK & English & Protestant & common \\
Uruguay & Spanish & Catholic & civil/French \\
US & English & Protestant & common \\
Venezuela & Spanish & Catholic & civil/French \\
Zimbabwe & English & Syncretic & common \\
\hline
\end{tabular}


Table 2: Averages of investor rights variables for different cultures. The table shows averages of shareholder rights, creditor rights, and investor rights enforcement variables for different religions and languages. The primary religion (language) of a country is the religion practiced (language spoken) by the largest fraction of the population. The data on religion and language is obtained from the 2000 CIA World Factbook. ${ }^{*}$ indicates unequal variances at the $10 \%$ level thus $\mathrm{t}$-statistics are calculated assuming unequal variances.

\section{Panel A: Shareholder Rights.}

\begin{tabular}{|c|c|c|c|c|c|c|c|c|c|}
\hline \multirow[b]{2}{*}{ Variable } & \multicolumn{3}{|c|}{ Primary Language } & \multicolumn{3}{|c|}{ Primary Religion } & \multicolumn{3}{|c|}{ Primary Religion } \\
\hline & English & Non-English & t-stat & Christian & Non-Christian & t-stat & Catholic & Protestant & t-stat \\
\hline $\mathrm{N}$ & 10 & 39 & & 32 & 17 & & 20 & 12 & \\
\hline One share one vote & 0.000 & 0.282 & $3.86^{*}$ & 0.156 & 0.353 & 1.45 & 0.200 & 0.083 & -0.94 \\
\hline $\begin{array}{l}\text { Proxy by mail } \\
\text { allowed }\end{array}$ & 0.600 & 0.077 & $-3.10^{*}$ & 0.250 & 0.059 & $-1.96^{*}$ & 0.100 & 0.500 & $2.41^{*}$ \\
\hline $\begin{array}{l}\text { Shares not blocked } \\
\text { before meeting }\end{array}$ & 1.000 & 0.641 & $-4.61^{*}$ & 0.625 & 0.882 & $2.17^{*}$ & 0.500 & 0.833 & 2.08 \\
\hline $\begin{array}{l}\text { Cumulative voting } \\
\text { / proportional rep }\end{array}$ & 0.200 & 0.282 & 0.51 & 0.250 & 0.294 & 0.32 & 0.350 & 0.083 & $-1.94^{*}$ \\
\hline $\begin{array}{l}\text { Oppressed } \\
\text { Minority }\end{array}$ & 1.000 & 0.410 & $-7.39^{*}$ & 0.469 & 0.647 & 1.19 & 0.400 & 0.583 & 0.98 \\
\hline $\begin{array}{l}\text { Preemptive right to } \\
\text { new issues }\end{array}$ & 0.300 & 0.590 & 1.68 & 0.625 & 0.353 & -1.84 & 0.750 & 0.417 & -1.86 \\
\hline $\begin{array}{l}\% \text { share capital to } \\
\text { call ESM }\end{array}$ & 0.075 & 0.120 & $3.08^{*}$ & 0.115 & 0.101 & -0.79 & 0.138 & 0.079 & $-2.79^{*}$ \\
\hline Anti-director rights & 4.10 & 2.72 & -4.04 & 2.94 & 3.12 & 0.47 & 2.65 & 3.42 & 1.58 \\
\hline $\begin{array}{l}\text { Mandatory } \\
\text { dividend }\end{array}$ & 0.000 & 0.060 & $2.50^{*}$ & 0.063 & 0.021 & $-1.22^{*}$ & 0.100 & 0.000 & $-2.36^{*}$ \\
\hline
\end{tabular}


Table 2, Continued.

Panel B: Creditor Rights.

\begin{tabular}{|c|c|c|c|c|c|c|c|c|c|}
\hline \multirow[b]{2}{*}{ Variable } & \multicolumn{3}{|c|}{ Primary Language } & \multicolumn{3}{|c|}{ Primary Religion } & \multicolumn{3}{|c|}{ Primary Religion } \\
\hline & English & Non-English & t-stat & Christian & Non-Christian & t-stat & Catholic & Protestant & t-stat \\
\hline $\mathrm{N}$ & 10 & 39 & & 32 & 17 & & 20 & 12 & \\
\hline $\begin{array}{l}\text { No automatic } \\
\text { stay on assets }\end{array}$ & 0.500 & 0.487 & -0.07 & 0.323 & 0.813 & 3.71 & 0.211 & 0.500 & 1.62 \\
\hline $\begin{array}{l}\text { Secured creditors } \\
\text { paid first }\end{array}$ & 0.900 & 0.778 & -1.00 & 0.767 & 0.875 & 0.93 & 0.684 & 0.909 & 1.58 \\
\hline $\begin{array}{l}\text { Restrictions for } \\
\text { going into } \\
\text { reorganization }\end{array}$ & 0.600 & 0.541 & -0.32 & 0.452 & 0.750 & 2.07 & 0.316 & 0.667 & 1.95 \\
\hline $\begin{array}{l}\text { Management } \\
\text { does not stay in } \\
\text { reorganization }\end{array}$ & 0.600 & 0.405 & -1.07 & 0.226 & 0.875 & 5.67 & 0.105 & 0.417 & $1.88^{*}$ \\
\hline Creditor rights & 2.600 & 2.22 & -0.76 & 1.77 & 3.31 & 4.57 & 1.32 & 2.50 & 2.93 \\
\hline $\begin{array}{l}\text { Legal reserve as } \\
\text { a \% of capital }\end{array}$ & 0.000 & 0.194 & $5.89^{*}$ & 0.155 & 0.155 & $0.00^{*}$ & 0.185 & 0.104 & -1.41 \\
\hline
\end{tabular}


Table 2, Continued.

Panel C: Rule of Law.

\begin{tabular}{|c|c|c|c|c|c|c|c|c|c|}
\hline \multirow[b]{2}{*}{ Variable } & \multicolumn{3}{|c|}{ Primary Language } & \multicolumn{3}{|c|}{ Primary Religion } & \multicolumn{3}{|c|}{ Primary Religion } \\
\hline & English & Non-English & t-stat & Christian & Non-Christian & t-stat & Catholic & Protestant & t-stat \\
\hline $\mathrm{N}$ & 10 & 39 & & 32 & 17 & & 20 & 12 & \\
\hline $\begin{array}{l}\text { Efficiency of Judicial } \\
\text { System }\end{array}$ & 8.450 & 7.466 & -1.55 & 7.914 & 7.201 & -1.07 & 7.325 & 8.896 & 2.46 \\
\hline Rule of Law & 7.262 & 6.740 & -0.52 & 7.624 & 5.383 & -3.21 & 7.049 & 8.583 & 1.79 \\
\hline Corruption & 7.696 & 6.692 & -1.20 & 7.499 & 5.762 & -2.74 & 6.788 & 8.685 & 2.69 \\
\hline Risk of expropriation & 8.179 & 8.017 & -0.24 & 8.050 & 7.295 & -2.69 & 8.106 & 9.028 & 1.75 \\
\hline $\begin{array}{l}\text { Risk of contract } \\
\text { repudiation }\end{array}$ & 7.688 & 7.553 & -0.20 & 8.036 & 6.722 & -2.60 & 7.575 & 8.805 & 2.31 \\
\hline $\begin{array}{l}\text { Rating on accounting } \\
\text { standards }\end{array}$ & 71.00 & 58.85 & $-3.72^{*}$ & 61.07 & 60.58 & -0.10 & 54.83 & 71.27 & 4.51 \\
\hline GNP per capita (US \$) & 10,994 & 11,197 & 0.06 & 13,517 & 6,712 & -2.40 & 11,422 & 17,009 & 1.60 \\
\hline
\end{tabular}


Table 3 : Multiple Regressions. The table shows the multiple regression results for the religion and language variables. The primary religion (language) of a country is the religion practiced (language spoken) by the largest fraction of the population. The data on religion and language is obtained from the 2000 CIA World Factbook. The dummy variables PROTESTANT, CATHOLIC, MUSLIM, BUDDHIST, ENGLISH, and SPANISH take value one if the name of the variable describes the primary religion or the primary language of the country and zero otherwise. a, b, c denotes that the F-test of no difference between PROTESTANT and CATHOLIC or ENGLISH and SPANISH is significant at the 1,5, and $10 \%$ level respectively, and ***,**,* denotes that the $\mathrm{t}$-statistic is significant at the 1,5 , and $10 \%$ level respectively.

\begin{tabular}{|c|c|c|c|c|c|c|c|c|c|}
\hline & $\begin{array}{l}\text { Log of GNP } \\
\text { per capita in } \\
\text { US\$ }\end{array}$ & CATHOLIC & $\begin{array}{l}\text { PROTES- } \\
\text { TANT }\end{array}$ & MUSLIM & BUDDHIST & ENGLISH & SPANISH & Intercept & $\begin{array}{c}\mathrm{N} \\
\text { Adjusted } \mathrm{R}^{2}\end{array}$ \\
\hline \multicolumn{10}{|c|}{ Panel A: Shareholder Rights } \\
\hline $\begin{array}{l}\text { Anti-Director } \\
\text { Rights }\end{array}$ & $\begin{array}{l}0.0107 \\
(0.09)\end{array}$ & $\begin{array}{c}-0.4789 \\
(-1.15)\end{array}$ & $\begin{array}{c}0.2820 \\
(0.58)\end{array}$ & & & & & $\begin{array}{c}3.0347 \\
(2.97)^{* * *}\end{array}$ & $\begin{array}{c}49 \\
-0.0045\end{array}$ \\
\hline $\begin{array}{l}\text { Anti-Director } \\
\text { Rights }\end{array}$ & $\begin{array}{c}-0.0349 \\
(-0.28)\end{array}$ & $\begin{array}{c}-0.9233 \\
(-1.42)\end{array}$ & $\begin{array}{c}-0.1380 \\
(-0.20)\end{array}$ & $\begin{array}{c}-0.9271 \\
(-1.21)\end{array}$ & $\begin{array}{l}-0.3766 \\
(-0.546)\end{array}$ & & & $\begin{array}{c}3.8808 \\
(3.48)^{* * *}\end{array}$ & $\begin{array}{c}49 \\
-0.0183\end{array}$ \\
\hline $\begin{array}{l}\text { Anti-Director } \\
\text { Rights }\end{array}$ & $\begin{array}{c}0.0403 \\
(0.30)\end{array}$ & & & & & $\begin{array}{c}1.4151^{\mathrm{a}} \\
(4.05)^{* * *}\end{array}$ & $\begin{array}{c}0.1070 \\
(0.20)\end{array}$ & $\begin{array}{l}2.3458 \\
(1.88)^{*}\end{array}$ & $\begin{array}{c}49 \\
0.1338\end{array}$ \\
\hline \multicolumn{10}{|c|}{ Panel B: Creditor Rights } \\
\hline Creditor Rights & $\begin{array}{c}-0.1643 \\
(-1.38)\end{array}$ & $\begin{array}{l}-1.8228^{\mathrm{a}} \\
(-4.17)^{* * *}\end{array}$ & $\begin{array}{l}-0.5583 \\
(-1.26)\end{array}$ & & & & & $\begin{array}{c}4.5926 \\
(5.29) * * *\end{array}$ & $\begin{array}{c}47 \\
0.3991\end{array}$ \\
\hline Creditor Rights & $\begin{array}{c}-0.1296 \\
(-0.99)\end{array}$ & $\begin{array}{l}-1.9793^{\mathrm{a}} \\
(-2.95)^{* * *}\end{array}$ & $\begin{array}{c}-0.7317 \\
(-1.06)\end{array}$ & $\begin{array}{l}0.1082 \\
(0.17)\end{array}$ & $\begin{array}{c}-0.5132 \\
(-0.76)\end{array}$ & & & $\begin{array}{c}4.4424 \\
(4.22) * * *\end{array}$ & $\begin{array}{c}47 \\
0.3835\end{array}$ \\
\hline Creditor Rights & $\begin{array}{c}-0.3448 \\
(-3.07) * * *\end{array}$ & & & & & $\begin{array}{c}0.0025^{\mathrm{b}} \\
(0.01)\end{array}$ & $\begin{array}{c}-1.3389 \\
(-2.45)^{* *}\end{array}$ & $\begin{array}{c}5.4962 \\
(5.25) * * *\end{array}$ & $\begin{array}{c}47 \\
0.1832 \\
\end{array}$ \\
\hline
\end{tabular}




\begin{tabular}{|c|c|c|c|c|c|c|c|c|c|}
\hline & $\begin{array}{l}\text { Log of GNP } \\
\text { per capita in } \\
\text { US\$ }\end{array}$ & CATHOLIC & $\begin{array}{c}\text { PROTES- } \\
\text { TANT }\end{array}$ & MUSLIM & BUDDHIST & ENGLISH & SPANISH & Intercept & $\begin{array}{c}\mathrm{N} \\
\text { Adjusted } \mathrm{R}^{2}\end{array}$ \\
\hline \multicolumn{10}{|c|}{ Panel C: Rule of Law } \\
\hline $\begin{array}{l}\text { Efficiency of } \\
\text { judiciary } \\
\text { system }\end{array}$ & $\begin{array}{c}0.8981 \\
(6.57)^{* * *}\end{array}$ & $\begin{array}{c}-0.8233^{b} \\
(-1.53)\end{array}$ & $\begin{array}{c}0.2678 \\
(0.45)\end{array}$ & & & & & $\begin{array}{c}0.2396 \\
(0.18)\end{array}$ & $\begin{array}{c}49 \\
0.4340\end{array}$ \\
\hline $\begin{array}{l}\text { Efficiency of } \\
\text { judiciary } \\
\text { system }\end{array}$ & $\begin{array}{c}0.8981 \\
(6.11)^{* * *}\end{array}$ & $\begin{array}{l}-1.8615^{b} \\
(-2.83)^{* * *}\end{array}$ & $\begin{array}{c}-0.7703 \\
(-1.08)\end{array}$ & $\begin{array}{l}-1.3057 \\
(-1.15)\end{array}$ & $\begin{array}{c}-1.7015 \\
(-1.53)\end{array}$ & & & $\begin{array}{l}1.2775 \\
(0.94)\end{array}$ & $\begin{array}{c}49 \\
0.4525\end{array}$ \\
\hline $\begin{array}{l}\text { Efficiency of } \\
\text { judiciary } \\
\text { system }\end{array}$ & $\begin{array}{c}0.8756 \\
(5.48) * * *\end{array}$ & & & & & $\begin{array}{l}1.0306^{\mathrm{a}} \\
(2.24)^{* *}\end{array}$ & $\begin{array}{c}-0.5846 \\
(-1.13)\end{array}$ & $\begin{array}{c}0.0594 \\
(0.04)\end{array}$ & $\begin{array}{c}49 \\
0.4465\end{array}$ \\
\hline Rule of law & $\begin{array}{c}1.4461 \\
(8.62)^{* * *}\end{array}$ & $\begin{array}{c}0.1400 \\
(0.28)\end{array}$ & $\begin{array}{c}0.9011 \\
(1.40)\end{array}$ & & & & & $\begin{array}{c}-5.8256 \\
(-4.53)^{* * *}\end{array}$ & $\begin{array}{c}49 \\
0.7578\end{array}$ \\
\hline Rule of law & $\begin{array}{c}1.4675 \\
(7.29)^{* * *}\end{array}$ & $\begin{array}{c}0.5134 \\
(0.59)\end{array}$ & $\begin{array}{l}1.2630 \\
(1.30)\end{array}$ & $\begin{array}{c}0.6421 \\
(0.75)\end{array}$ & $\begin{array}{c}0.4471 \\
(0.48)\end{array}$ & & & $\begin{array}{c}-6.3872 \\
(-3.53)^{* * *}\end{array}$ & $\begin{array}{c}49 \\
0.7505\end{array}$ \\
\hline Rule of law & $\begin{array}{c}1.5093 \\
(12.75)^{* * *}\end{array}$ & & & & & $\begin{array}{c}0.6694^{b} \\
(1.51)\end{array}$ & $\begin{array}{c}-0.7145 \\
(-1.27)\end{array}$ & $\begin{array}{c}-6.0944 \\
(-5.73)^{* * *}\end{array}$ & $\begin{array}{c}49 \\
0.7688\end{array}$ \\
\hline Corruption & $\begin{array}{c}1.2609 \\
(12.23)^{* * *}\end{array}$ & $\begin{array}{c}-0.3049^{\mathrm{a}} \\
(-1.01)\end{array}$ & $\begin{array}{c}0.9186 \\
(2.01)^{* *}\end{array}$ & & & & & $\begin{array}{c}-4.0106 \\
(-4.39)^{* * *}\end{array}$ & $\begin{array}{c}49 \\
0.7793\end{array}$ \\
\hline Corruption & $\begin{array}{c}1.2339 \\
(11.21)^{* * *}\end{array}$ & $\begin{array}{c}-0.9791^{\mathrm{a}} \\
(-2.68)^{* * *}\end{array}$ & $\begin{array}{c}0.2589 \\
(0.52)\end{array}$ & $\begin{array}{l}-1.0662 \\
(-1.99)^{* *}\end{array}$ & $\begin{array}{c}-0.8964 \\
(-2.18)^{* *}\end{array}$ & & & $\begin{array}{c}-3.0984 \\
(-3.23)^{* * *}\end{array}$ & $\begin{array}{c}49 \\
0.7847\end{array}$ \\
\hline Corruption & $\begin{array}{c}1.3083 \\
(12.22) * * * \\
\end{array}$ & & & & & $\begin{array}{c}1.0878^{\mathrm{a}} \\
(2.85)^{* * *}\end{array}$ & $\begin{array}{c}-0.8105 \\
(-2.69)^{* *}\end{array}$ & $\begin{array}{c}-4.3894 \\
(-4.44) * * *\end{array}$ & $\begin{array}{c}49 \\
0.8065 \\
\end{array}$ \\
\hline
\end{tabular}




\begin{tabular}{|c|c|c|c|c|c|c|c|c|c|}
\hline & $\begin{array}{l}\text { Log of GNP } \\
\text { per capita in } \\
\text { US\$ }\end{array}$ & CATHOLIC & $\begin{array}{c}\text { PROTES- } \\
\text { TANT }\end{array}$ & MUSLIM & BUDDHIST & ENGLISH & SPANISH & Intercept & $\begin{array}{c}\mathrm{N} \\
\text { Adjusted } \mathrm{R}^{2}\end{array}$ \\
\hline $\begin{array}{l}\text { Risk of } \\
\text { expropriation }\end{array}$ & $\begin{array}{c}0.9274 \\
(11.28)^{* * *}\end{array}$ & $\begin{array}{c}-0.1678^{c} \\
(-0.64)\end{array}$ & $\begin{array}{l}0.2596 \\
(1.09)\end{array}$ & & & & & $\begin{array}{l}0.1067 \\
(0.15)\end{array}$ & $\begin{array}{c}49 \\
0.7840\end{array}$ \\
\hline $\begin{array}{l}\text { Risk of } \\
\text { expropriation }\end{array}$ & $\begin{array}{c}0.9245 \\
(9.09)^{* * *}\end{array}$ & $\begin{array}{c}-0.0051^{\mathrm{c}} \\
(-0.01)\end{array}$ & $\begin{array}{l}0.4239 \\
(0.75)\end{array}$ & $\begin{array}{l}0.1815 \\
(0.25)\end{array}$ & $\begin{array}{l}0.2888 \\
(0.49)\end{array}$ & & & $\begin{array}{l}-0.0307 \\
(-0.02)\end{array}$ & $\begin{array}{c}49 \\
0.7760\end{array}$ \\
\hline $\begin{array}{l}\text { Risk of } \\
\text { expropriation }\end{array}$ & $\begin{array}{c}0.9152 \\
(10.59)^{* * *}\end{array}$ & & & & & $\begin{array}{c}0.1908^{b} \\
(0.90)\end{array}$ & $\begin{array}{c}-0.6951 \\
(-1.96)^{* *}\end{array}$ & $\begin{array}{c}0.2947 \\
(0.35)\end{array}$ & $\begin{array}{c}49 \\
0.8096\end{array}$ \\
\hline $\begin{array}{l}\text { Repudiation of } \\
\text { contracts by } \\
\text { government }\end{array}$ & $\begin{array}{c}1.0449 \\
(13.50)^{* * *}\end{array}$ & $\begin{array}{c}-0.2499^{\mathrm{a}} \\
(-0.85)\end{array}$ & $\begin{array}{l}0.4233 \\
(1.60)\end{array}$ & & & & & $\begin{array}{c}-1.3768 \\
(-2.15)^{* *}\end{array}$ & $\begin{array}{c}49 \\
0.8126\end{array}$ \\
\hline $\begin{array}{l}\text { Repudiation of } \\
\text { contracts by } \\
\text { government }\end{array}$ & $\begin{array}{c}1.0144 \\
(11.23)^{* * *}\end{array}$ & $\begin{array}{c}-0.0268^{\mathrm{a}} \\
(-0.06)\end{array}$ & $\begin{array}{l}0.6627 \\
(1.46)\end{array}$ & $\begin{array}{l}0.0346 \\
(0.06)\end{array}$ & $\begin{array}{l}0.6006 \\
(1.21)\end{array}$ & & & $\begin{array}{l}-1.3314 \\
(-1.37)\end{array}$ & $\begin{array}{c}49 \\
0.8120\end{array}$ \\
\hline $\begin{array}{l}\text { Repudiation of } \\
\text { contracts by } \\
\text { government }\end{array}$ & $\begin{array}{c}1.0377 \\
(14.24)^{* * *}\end{array}$ & & & & & $\begin{array}{c}0.1622^{b} \\
(0.79)\end{array}$ & $\begin{array}{c}-0.8141 \\
(-2.07)^{* *}\end{array}$ & $\begin{array}{l}-1.1967 \\
(-1.70)^{*}\end{array}$ & $\begin{array}{c}49 \\
0.8274\end{array}$ \\
\hline $\begin{array}{l}\text { Accounting } \\
\text { standards }\end{array}$ & $\begin{array}{c}4.6241 \\
(2.93)^{* * *}\end{array}$ & $\begin{array}{l}-8.4520^{\mathrm{a}} \\
(-2.01)^{* *}\end{array}$ & $\begin{array}{l}4.2141 \\
(1.15)\end{array}$ & & & & & $\begin{array}{c}22.2962 \\
(1.47)\end{array}$ & $\begin{array}{c}41 \\
0.3798\end{array}$ \\
\hline $\begin{array}{l}\text { Accounting } \\
\text { standards }\end{array}$ & $\begin{array}{c}4.1350 \\
(2.69)^{* * *}\end{array}$ & $\begin{array}{l}-7.9700^{\mathrm{a}} \\
(-1.92)^{*}\end{array}$ & $\begin{array}{l}5.0953 \\
(1.31)\end{array}$ & $\begin{array}{c}-2.8474 \\
(-0.28)\end{array}$ & $\begin{array}{l}3.4362 \\
(0.81)\end{array}$ & & & $\begin{array}{c}26.1497 \\
(1.89)^{*}\end{array}$ & $\begin{array}{c}41 \\
0.3548\end{array}$ \\
\hline $\begin{array}{l}\text { Accounting } \\
\text { standards }\end{array}$ & $\begin{array}{c}4.2728 \\
(2.72)^{* * *}\end{array}$ & & & & & $\begin{array}{l}9.3506^{\mathrm{a}} \\
(3.55)^{* * *}\end{array}$ & $\begin{array}{l}-10.7905 \\
(-2.23)^{* *}\end{array}$ & $\begin{array}{c}23.3566 \\
(1.51)\end{array}$ & $\begin{array}{c}41 \\
0.4228\end{array}$ \\
\hline
\end{tabular}


Table 4. Culture and Law Interactions. The table shows the interaction between the culture (religion or language) and the legal origin (civil or common) variables. $* * * * * * *$ denotes the significance of the t-test at the 1, 5, and $10 \%$ significance levels respectively. a, b, c denotes that the F-statistic of no difference between Catholic, Protestant, and non-Christian, or English and Spanish keeping legal origins constant is significant at the 1,5, and 10\% level respectively. 1, 2, 3 denotes that F-statistic of no difference between civil and common legal origin keeping the religion or the language the same is significant at the 1,5 , and $10 \%$ level respectively.

\begin{tabular}{|c|c|c|c|c|}
\hline & $\begin{array}{l}\text { Anti-Director } \\
\text { Rights }\end{array}$ & $\begin{array}{l}\text { Anti-Director } \\
\text { Rights }\end{array}$ & Creditor Rights & Creditor Rights \\
\hline $\log (\mathrm{GNP})$ is US\$ & $\begin{array}{l}0.0847 \\
(0.72)\end{array}$ & $\begin{array}{l}0.1649 \\
(1.79)^{*}\end{array}$ & $\begin{array}{l}-0.1111 \\
(-0.89)\end{array}$ & $\begin{array}{l}-0.2315 \\
(-1.75)^{*}\end{array}$ \\
\hline $\begin{array}{l}\text { Civil Law and } \\
\text { Protestant }\end{array}$ & $\begin{array}{l}-1.4021^{1} \\
(-2.41)^{* *}\end{array}$ & & $\begin{array}{l}-1.2016^{b} \\
(-2.53)^{* *}\end{array}$ & \\
\hline $\begin{array}{l}\text { Common Law and } \\
\text { Protestant }\end{array}$ & $\begin{array}{c}0.5248 \\
(1.09)\end{array}$ & & $\begin{array}{l}-0.9910^{\mathrm{a}} \\
(-1.86)^{*}\end{array}$ & \\
\hline $\begin{array}{l}\text { Civil Law and } \\
\text { Catholic }\end{array}$ & $\begin{array}{l}-1.3573^{1} \\
(-2.92)^{* * *}\end{array}$ & & $\begin{array}{c}-2.3086 \\
(-5.46)^{* * *}\end{array}$ & \\
\hline $\begin{array}{l}\text { Common Law and } \\
\text { Catholic }\end{array}$ & $\begin{array}{c}0.6152 \\
(1.13)\end{array}$ & & $\begin{array}{c}-2.5577 \\
(-7.95)^{* * *}\end{array}$ & \\
\hline $\begin{array}{l}\text { Civil Law and Non- } \\
\text { Christian }\end{array}$ & $\begin{array}{l}-1.4645^{1} \\
(-3.18)^{* * *}\end{array}$ & & $\begin{array}{l}-1.2153^{b} \\
(-2.45)^{* *}\end{array}$ & \\
\hline $\begin{array}{l}\text { Common Law and } \\
\text { English }\end{array}$ & & $\begin{array}{c}1.9424 \\
(6.71)^{* * *}\end{array}$ & & $\begin{array}{l}0.4636 \\
(0.94)\end{array}$ \\
\hline $\begin{array}{l}\text { Civil Law and } \\
\text { Spanish }\end{array}$ & & $\begin{array}{l}0.6781 \\
(1.35)\end{array}$ & & $\begin{array}{l}-0.8395 \\
(-1.46)\end{array}$ \\
\hline $\begin{array}{l}\text { Common Law and } \\
\text { No Spanish or } \\
\text { English }\end{array}$ & & $\begin{array}{c}1.8027 \\
(4.05)^{* * *}\end{array}$ & & $\begin{array}{c}1.4939 \\
(3.47)^{* * *}\end{array}$ \\
\hline Intercept & $\begin{array}{c}3.0639 \\
(3.12)^{* * * *}\end{array}$ & $\begin{array}{l}0.7711 \\
(0.955)\end{array}$ & $\begin{array}{c}4.6340 \\
(4.89)^{* * *}\end{array}$ & $\begin{array}{c}4.0825 \\
(3.07) * * *\end{array}$ \\
\hline $\begin{array}{l}\mathrm{N} \\
\text { Adjusted } \mathrm{R}^{2}\end{array}$ & $\begin{array}{c}49 \\
0.2930\end{array}$ & $\begin{array}{c}49 \\
0.3465\end{array}$ & $\begin{array}{c}49 \\
0.4282\end{array}$ & $\begin{array}{c}47 \\
0.3123\end{array}$ \\
\hline
\end{tabular}


Table 5: Openness and Finance. The table shows the relationship between openness, culture and the law category. Natural openness measured using the 1985 actual openness adjusted for geography as done in Frankel and Romer (1999). CATHOLIC, PROTESTANT, ENGLISH, and SPANISH are dummy variables that take value one if the name of the variable corresponds to the primary religion or the primary language of a country. a, b, c denotes that the F-statistc for the test that CATHOLIC and PROTESTANT are equal or SPANISH and ENGLISH are equal is significant at the 1,5, and $10 \%$ level of significance and $* * *, * *$, * denotes that the $\mathrm{t}$-statistic $\mathrm{t}$ is significant at the 1,5 , and $10 \%$ levels.

\begin{tabular}{|c|c|c|c|c|c|c|c|c|c|}
\hline & $\begin{array}{l}\text { Log of GNP } \\
\text { per capita in } \\
\text { US\$ }\end{array}$ & $\begin{array}{l}\text { Natural } \\
\text { openness }\end{array}$ & $\begin{array}{l}\text { Civil Law } \\
\text { Dummy } \\
\text { (CIVOR) }\end{array}$ & CATHOLIC & $\begin{array}{l}\text { PROTES- } \\
\text { TANT }\end{array}$ & ENGLISH & SPANISH & Intercept & $\begin{array}{c}\mathrm{N} \\
\text { Adjust } \\
\text { ed } \mathrm{R}^{2}\end{array}$ \\
\hline \multicolumn{10}{|c|}{ Panel A: Shareholder Rights } \\
\hline $\begin{array}{l}\text { Anti-Director } \\
\text { Rights }\end{array}$ & $\begin{array}{c}0.2821 \\
(2.95)^{* * *}\end{array}$ & $\begin{array}{c}-0.0330 \\
(-3.27)^{* * *}\end{array}$ & $\begin{array}{c}-1.8980 \\
(-4.01)^{* * *}\end{array}$ & $\begin{array}{c}-0.1784 \\
(-0.48)\end{array}$ & $\begin{array}{c}-0.0881 \\
(-0.23)\end{array}$ & $\begin{array}{c}-0.2599 \\
(-0.45)\end{array}$ & $\begin{array}{c}0.4466 \\
(0.78)\end{array}$ & $\begin{array}{c}2.4350 \\
(2.70)^{* * *}\end{array}$ & $\begin{array}{c}49 \\
0.4226\end{array}$ \\
\hline \multicolumn{10}{|c|}{ Panel B: Creditor Rights } \\
\hline Creditor Rights & $\begin{array}{c}-0.3314 \\
(-2.83) * * *\end{array}$ & $\begin{array}{c}0.0385 \\
(3.68) * * *\end{array}$ & $\begin{array}{c}-0.5988 \\
(-1.29)\end{array}$ & $\begin{array}{c}-1.4283^{\mathrm{a}} \\
(-2.71)^{* * *}\end{array}$ & $\begin{array}{c}-0.0330 \\
(-0.07)\end{array}$ & $\begin{array}{c}-0.1734 \\
(-0.36)\end{array}$ & $\begin{array}{c}0.2784 \\
(0.47)\end{array}$ & $\begin{array}{c}5.4470 \\
(6.16)^{* * *}\end{array}$ & $\begin{array}{c}47 \\
0.4849\end{array}$ \\
\hline \multicolumn{10}{|c|}{ Panel C: Rule of Law } \\
\hline $\begin{array}{l}\text { Efficiency of } \\
\text { judiciary }\end{array}$ & $\begin{array}{l}0.7757 \\
(4.45)\end{array}$ & $\begin{array}{c}0.0490 \\
(3.43)\end{array}$ & $\begin{array}{c}-0.9770 \\
(-1.07)\end{array}$ & $\begin{array}{c}-0.2720^{c} \\
(-0.38)\end{array}$ & $\begin{array}{c}0.6336 \\
(0.78)\end{array}$ & $\begin{array}{l}0.5772 \\
(0.56)\end{array}$ & $\begin{array}{c}0.5880 \\
(1.09)\end{array}$ & $\begin{array}{c}0.4953 \\
(0.29)\end{array}$ & $\begin{array}{c}49 \\
0.5550\end{array}$ \\
\hline Rule of law & $\begin{array}{c}1.4043 \\
(7.94)^{* * *}\end{array}$ & $\begin{array}{c}-0.0070 \\
(-0.54)\end{array}$ & $\begin{array}{l}0.1071 \\
(0.19)\end{array}$ & $\begin{array}{c}0.6606 \\
(1.24)\end{array}$ & $\begin{array}{c}0.7673 \\
(1.15)\end{array}$ & $\begin{array}{c}0.3849^{b} \\
(0.60)\end{array}$ & $\begin{array}{l}-1.2233 \\
(-1.72)^{*}\end{array}$ & $\begin{array}{c}-5.4443 \\
(-3.70)^{* * *}\end{array}$ & $\begin{array}{c}49 \\
0.7625\end{array}$ \\
\hline Corruption & $\begin{array}{c}1.1644 \\
(10.72)^{* * *}\end{array}$ & $\begin{array}{c}0.0215 \\
(2.66) * * *\end{array}$ & $\begin{array}{l}-0.7885 \\
(-1.93)^{*}\end{array}$ & $\begin{array}{c}0.5188 \\
(1.17)\end{array}$ & $\begin{array}{c}1.1617 \\
(2.26)^{* *}\end{array}$ & $\begin{array}{c}0.2978 \\
(0.51)\end{array}$ & $\begin{array}{c}-0.5427 \\
(-1.12)\end{array}$ & $\begin{array}{c}-3.4239 \\
(-3.50) * * *\end{array}$ & $\begin{array}{c}49 \\
0.8279\end{array}$ \\
\hline $\begin{array}{l}\text { Risk of } \\
\text { expropriation }\end{array}$ & $\begin{array}{c}0.8977 \\
(8.77) * * *\end{array}$ & $\begin{array}{c}-0.0090 \\
(-1.61)\end{array}$ & $\begin{array}{c}-0.3534 \\
(-0.93)\end{array}$ & $\begin{array}{l}0.4276 \\
(1.03)\end{array}$ & $\begin{array}{c}0.4000 \\
(1.27)\end{array}$ & $\begin{array}{c}-0.3058 \\
(-0.67)\end{array}$ & $\begin{array}{l}-0.9523 \\
(-2.00)^{* *}\end{array}$ & $\begin{array}{c}0.7109 \\
(0.69)\end{array}$ & $\begin{array}{c}49 \\
0.8074\end{array}$ \\
\hline $\begin{array}{l}\text { Repudiation of } \\
\text { contracts }\end{array}$ & $\begin{array}{c}1.0003 \\
(9.95)^{* * *}\end{array}$ & $\begin{array}{c}-0.0081 \\
(-1.00)\end{array}$ & $\begin{array}{c}-0.4004 \\
(-1.11)\end{array}$ & $\begin{array}{l}0.3979 \\
(0.95)\end{array}$ & $\begin{array}{l}0.6565 \\
(1.87)^{*}\end{array}$ & $\begin{array}{l}-0.4644 \\
(-1.24)\end{array}$ & $\begin{array}{l}-0.9923 \\
(-1.99)^{* *}\end{array}$ & $\begin{array}{c}-0.6413 \\
(-0.76)\end{array}$ & $\begin{array}{c}49 \\
0.8302\end{array}$ \\
\hline $\begin{array}{l}\text { Accounting } \\
\text { standards }\end{array}$ & $\begin{array}{c}4.9611 \\
(2.82)^{* * *}\end{array}$ & $\begin{array}{c}-0.1634 \\
(-1.57) \\
\end{array}$ & $\begin{array}{c}-16.8076 \\
(-3.09) * * *\end{array}$ & $\begin{array}{l}2.9875 \\
(0.53)\end{array}$ & $\begin{array}{l}8.4387 \\
(1.83) *\end{array}$ & $\begin{array}{c}-9.4322 \\
(-1.40) \\
\end{array}$ & $\begin{array}{c}-8.5084 \\
(-1.40) \\
\end{array}$ & $\begin{array}{l}30.7001 \\
(2.26)^{* *}\end{array}$ & $\begin{array}{c}41 \\
0.5208 \\
\end{array}$ \\
\hline
\end{tabular}


Table 6. Incremental Explanatory Power. This table shows the incremental adjusted $\mathrm{R}^{2}$ from adding OPENNESS, CIVOR, CIVOR3, PROTESTANT and CATHOLIC, or ENGLISH and SPANISH to regressions of investor rights variables on a constant and the log of GNP per capita. Natural openness is the Frankel and Romer (1999) measure of geographic openness. PROTESTANT, CATHOLIC, ENGLISH, and SPANISH are dummy variables that take value one if their name describes the primary religion or language of a country and zero otherwise. CIVOR takes value one if the origin of a country's legal system is civil law. ***, **, * denotes that the t-test is significant at the 1,5 , and $10 \%$ level respectively. CIVOR3 represents dummy variables for whether a country's civil law in of French, Scandinavian, or German origin. a, b, and c denotes that the F-statistic for the test that CATHOLIC and PROTESTANT are equal, that ENGLISH and SPANISH are equal, or that the dummy variables for the three distinct civil law origins are equal is significant at the 1,5 , and $10 \%$ level.

\begin{tabular}{|c|c|c|c|c|c|}
\hline & $\begin{array}{l}\text { Natural openness } \\
\quad\left(\text { Incr } \mathrm{R}^{2}\right)\end{array}$ & $\begin{array}{r}\text { CIVOR } \\
(\text { Incr R R })\end{array}$ & $\begin{array}{l}\text { CATHOLIC and } \\
\text { PROTESTANT } \\
\left.\quad(\text { Incr R })^{2}\right)\end{array}$ & $\begin{array}{l}\text { ENGLISH } \\
\text { and } \\
\text { SPANISH } \\
\left(\text { Incr R }{ }^{2}\right)\end{array}$ & $\begin{array}{l}\text { CIVOR3 } \\
(\text { Incr R R })\end{array}$ \\
\hline Anti-Director Rights & $0.1036^{* *}$ & $0.3596 * * *$ & 0.0165 & $0.1548^{b}$ & 0.3430 \\
\hline Creditor Rights & $0.1222 * * *$ & $0.1561 * * *$ & $0.3176^{\mathrm{a}}$ & $0.1017^{b}$ & $0.2124^{b}$ \\
\hline $\begin{array}{l}\text { Efficiency of } \\
\text { judiciary system }\end{array}$ & $0.0574 * *$ & $0.0941 * * *$ & $0.0306^{\mathrm{c}}$ & $0.0431^{b}$ & $0.1296^{b}$ \\
\hline Rule of law & -0.0028 & $-0.0009 * * *$ & 0.0069 & $0.0179^{b}$ & 0.0028 \\
\hline Corruption & 0.0011 & 0.0530 & $0.0352^{a}$ & $0.0624^{\mathrm{a}}$ & $0.0860^{\mathrm{a}}$ \\
\hline $\begin{array}{l}\text { Risk of } \\
\text { expropriation }\end{array}$ & -0.0028 & $0.0092 *$ & 0.0021 & $0.0277^{\mathrm{a}}$ & 0.0130 \\
\hline $\begin{array}{l}\text { Repudiation of } \\
\text { contracts by } \\
\text { government }\end{array}$ & -0.0032 & $0.0082 *$ & $0.0142^{b}$ & $0.0290^{\mathrm{a}}$ & $0.0342^{\mathrm{a}}$ \\
\hline $\begin{array}{l}\text { Accounting } \\
\text { standards }\end{array}$ & -0.0152 & $0.2447 * * *$ & $0.1370^{a}$ & $0.1800^{\mathrm{a}}$ & $0.3266^{\mathrm{a}}$ \\
\hline $\begin{array}{l}\text { Equity Issues to } \\
\text { GDP }\end{array}$ & -0.0138 & $0.1552 * *$ & 0.0399 & 0.0140 & 0.1091 \\
\hline $\begin{array}{l}\text { Long-Term Private } \\
\text { Debt Issues to GDP }\end{array}$ & -0.0224 & -0.0199 & $0.1472^{\mathrm{a}}$ & -0.0077 & $0.2378^{a}$ \\
\hline $\begin{array}{l}\text { Total Private Credit } \\
\text { to GDP }\end{array}$ & -0.0112 & $0.0211 *$ & 0.0586 & $0.0519^{b}$ & $0.1565^{\mathrm{a}}$ \\
\hline $\begin{array}{l}\text { Stock Market } \\
\text { capitalization to } \\
\text { GDP }\end{array}$ & -0.0082 & $0.2009 * * *$ & 0.1044 & $0.0373^{b}$ & 0.1960 \\
\hline
\end{tabular}

